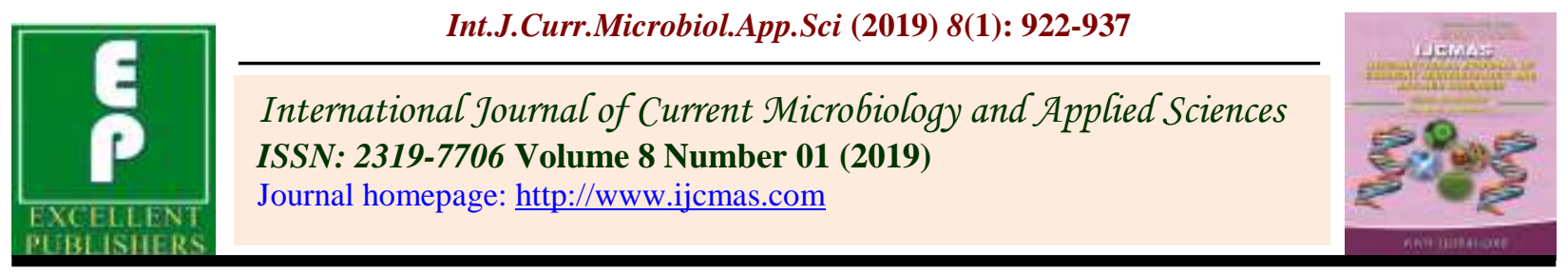

Original Research Article

https://doi.org/10.20546/ijcmas.2019.801.100

\title{
Study on Correlation between Population of Viruliferous Whitefly and the Percent Intensity of Cotton Leaf Curl Disease in Cotton
}

\author{
A. Kumar, S.K. Sain* and D. Monga
}

ICAR-Central Institute for Cotton Research, Regional Station, Sirsa 125055, Haryana, India

*Corresponding author

\begin{abstract}
Keywords
Cotton leaf curl disease, Correlation, Field study, Viruliferous whitefly, Percent disease index

Article Info

Accepted: 07 December 2018 Available Online: 10 January 2019 the role of alternative weed hosts, infested cotton plants is well understood. However, the relationship of viruliferous whitefly population and CLCuD incidence is still not clear. We aimed to pursue a detailed study on the effect of general whitefly population and viruliferous whitefly population on $\mathrm{CLCuD}$ percent disease index (PDI) and their correlation. Three years study showed a decreasing trend in general whitefly population and increasing trend in viruliferous whitefly population in correspondence with the increase in CLCuD intensity from August to October. A highly significant and positive correlation between viruliferous whitefly population on cotton plant and percent diseases index of CLCuD $\left(r^{2}=0.945\right)$ was observed both at on-station and on-farm multilocation trials. A non-significant positive correlation between whitefly population and CLCuD PDI $\left(r^{2}=0.796\right)$ and between whitefly population and viruliferous whitefly population $\left(\mathrm{r}^{2}=\right.$ 0.633 ) was recorded at on-station trials. Thus, it's one of its first kinds of research study which shows a positive correlation between viruliferous whitefly population and the level of CLCuD intensity in cotton field for the first time. These results advance our understanding on timely detection of viruliferous whitefly level in the cotton field during the off-season as well as during the crop season. This would help in managing the transmission of $\mathrm{CLCuV}$ through the judicious and timely application of management strategies for viruliferous whitefly.
\end{abstract}

\section{A B S T R A C T}

Cotton Leaf Curl Disease (CLCuD) is a devastating disease in cotton and cause seed cotton yield loss upto $80 \%$ in Northern India. Transmission of CLCuD by Bemisia tabaci,

\section{Introduction}

Cotton (Gossypium spp.) known as "White Gold" is worlds' one of the most important commercial and natural textile fibre crops and a significant contributor of oilseeds. India is a leading producer of cotton in the world and is the only country in the world to cultivate all four cultivable Gossypium species i.e.,
Gossypium arboreum and G. herbaceum, G. barbadense and $G$. hirsutum besides hybrid cottons. Cotton is cultivated in three distinct agro-ecological regions (north, central and south) of the country. Cotton Leaf Curl Disease (CLCuD) is caused by Cotton leaf curl virus $(\mathrm{CLCuV})$ which belongs to begomovirus group, family Geminivirideae and has emerged as a serious threat to cotton 
cultivation in North India and Pakistan (Mansoor et al., 2003; Sattar et al., 2013; Varma and Malathi, 2003). In India, CLCuD is presently restricted to $1.2-2.0$ million ha in northern cotton growing states i.e. Haryana, Punjab and Rajasthan (Varma and Malathi, 2003) and is reported to cause potential yield losses from 25.2 - 81.4\% (Monga et al., 2013; Monga, 2014; Narula et al., 1999). A number of geminiviruses have been reported to infect cotton in the Indian subcontinent, including Cotton leaf curl Multan virus - Rajasthan (CLCuMuV-Ra), Cotton leaf curl Kokhran virus - Burewala (CLCuKoV-Bu), Papayaleaf curl virus (PaLCuV), Okra enation leaf curl virus (OEnLCV), Tomato leaf curl Bangalore virus (ToLCuBaV), Tomato leaf curl New Delhi virus (ToLCNDV). However, CLCuMuV and CLCuKoV or their strains such as with CLCuMuV-Ra, CLCuKoV-Bu are predominantly associated with CLCuD epidemics in the Indian subcontinent (Brown et al., 2017; Sattar et al., 2017). During 20042005, CLCuMuV-Ra was the major in northwestern India, but in 2009-10, resistant breaking CLCuKoV-Bu caused a severe outbreak of CLCuD in Punjab and Rajasthan states of India (Rajagopalan et al., 2012). However, during 2015-16, replacement of the 'virulent resistance breaking' CLCuKoV-Bu by the re-emerging $\mathrm{CLCuMuV}$ recombinants were recorded to cause an epidemic in North India (Datta et al., 2017).

Bemisia tabaci (Gennadius) (Hemiptera: Aleyrodidae) assumed major importance on cotton in India after severe outbreaks during 1984 - 85 and 1985 - 86 seasons in Andhra Pradesh, Karnataka and Tamil Nadu and later as a vector in transmission of CLCuD in Rajasthan, Haryana and Punjab during 1990s onward. Thus, the whitefly itself as well as a vector of CLCuD is assuming serious pest status of almost all cotton varieties. It was observed that the percent disease incidence (PDI) increased slowly during the month of
June and reached up to $80 \%$ during July and August in Sudan (Idris, 1990). Similarly, the $\mathrm{CLCuV}$ incidence increased rapidly from 4.3 to $12.3 \%$ during the end of July and first week of August in Pakistan (Ali et al., 1995). However, the progress of the disease was reported to be maximum during the month of August as compared to July and September in Northern India (Monga et al., 1998). In a recent study three $B$. tabaci biotypes were recorded from India include Asia-II-7 in Pusa -Delhi, Asia-I in south and central India and Asia-II-1 in north India (Naveen et al., 2017).

An effective management of this important disease and its vector is possible by the development of resistant varieties and suppression of whitefly along with the eradication of weed hosts carrying this disease. At present there is no source of absolute resistance against $\mathrm{CLCuV}$ in $G$ hirsutum cotton varieties and there is no chemical control for the CLCuD except the management of its vector whitefly.

Earlier studies conducted on correlation of whitefly, weather factors and CLCuD, reveal that the percent CLCuD incidence and whitefly population shows a negative correlation with maximum and minimum temperature and rainfall while positive correlation with morning and evening relative humidity and sunshine hours (Maharshi et al., 2017). Non-significant correlation between CLCuD intensity and whitefly population were reported on different cotton varieties (Varma and Malathi, 2003). The real positive correlation of whitefly populations vis-à-vis CLCuD development and its severity has not been established (Akhtar et al., 2004). However, disease severity of rice stripe virus (RSV) transmitted by small brown planthopper in paddy was reported to have a positive correlation with viruliferous rate of the vector but not with the population density of the insect. This suggests that the proportion 
of vectors infected by the virus rather than the total number of vectors plays an important role in RSV epidemics and could be used for disease forecasting (He et al., 2016). The literature available indicates that there is no such study available which could establish the correlation of the proportion of nonviruliferous and viruliferous whiteflies with CLCuD incidence and its percent severity or PDI in cotton. Hence, we intended to study the effect of general whitefly population and viruliferous whitefly population on CLCuD percent disease index (PDI) as well as to study their correlation. It was also felt that understanding the inoculum source becomes an important step in epidemiological studies, disease development and decision making for management of $\mathrm{CLCuD}$ transmission vector. The present studies were planned with a view to elucidate and understand the correlation of levels of viruliferous whiteflies population out of the existing whitefly populations in cotton leaf curl disease intensity.

\section{Materials and Methods}

\section{Selection of cotton fields for whitefly and CLCuD data recording}

The two types of field experiments, one at onstation and another at the hot spot locations were decided for conducting the study to understand the relationship between total whitefly population - viruliferous whitefly population and CLCuD PDI. These experiments were conducted twice during 2010 and 2011 at on-station and during 2011 and 2012 at hot spot locations. On-station trial was conducted at ICAR Central Institute for Cotton Research- Regional Station (ICARCICR-RS), Sirsa experimental farm (29³2'39.5"N 7502'24.6"E). CLCuD and whitefly susceptible variety HS 6 was sown with row to row and plant to plant spacing of $67.5 \times 30 \mathrm{~cm}$ in an area of $393 \mathrm{~m}^{2}$ with 1940 plants (twenty rows of 97 plants each).
Standard package and practices were followed to raise the crop. Another, on-farm hot spot location trial was conducted during 2011 and 2012 at three fixed locations situated in whitefly and CLCuD hot spot areas in Haryana, Rajasthan and Punjab. In Haryana, three locations, i.e. Umedpura, Jagmalwali and Fatehpuria were selected as hot spots based on previous research experience (Monga personal communication). In Rajasthan, three locations, namely Kaluwali, Sadhuwali and Agriculture Research StationSriganganagar and in Punjab- five locations, i.e. Mansa, Bathinda, Fazilka, Wander Jatna and Nihalkhera locations were selected for recording of whitefly population and CLCuD per cent disease index (PDI).

\section{Recording of whitefly population and progress in PDI of CLCuD at ICAR-CICR- RS, Sirsa}

Observations on total whitefly populationviruliferous whitefly population and CLCuD PDI were recorded at weekly interval during 2010 from the $25^{\text {th }}$ Standard Meteorological Week (SMW) to $41^{\text {st }}$ SMW and during 2011 from $25^{\text {th }}$ SMW to $44^{\text {th }}$ SMW (June to October). Data on whitefly population were taken on 50 randomly selected tagged cotton plants of HS-6 variety in five plots by selecting 10 plants in each. For determination of PDI of CLCuD, a total of 100 cotton plants were selected randomly in five plots of one acre field. 20 cotton plants were selected in each plot for the observation of CLCuD PDI. Observation of CLCuD on cotton plants from each point were recorded by observing CLCuD symptoms using 0-6 scale (Monga, 2014). The observations were taken at 0-6 disease rating scale where $0=$ complete absence of symptoms; 1 = symptoms of vein thickening (VT) on few upper leaves; 2 = symptoms of VT, cupping and curling on few upper leaves; $3=$ one fourth of a plant affected with VT, cupping and curling, leafy enations; 
$4=$ half plant of a plant affected with VT, cupping and curling, leaf enations; $5=$ three fourth of a plant affected with VT, cupping and curling, leafy enation; and $6=$ Plants stunted severely and complete plant affected with VT, cupping and curling and leafy enation. The average grade was calculated by using the formula: Average disease rating grade $=$ (Sum of all disease rating grades $/$ Total number of plants), and percent disease index (PDI) was calculated for each entry/plot by using the following formula: PDI= [Average disease rating grade /Maximum disease rating grade] $\mathrm{x} 100$

\section{Recording of whitefly population, viruliferous whitefly population and progress in PDI of CLCuD at different farmer field locations}

This study was undertaken to observe the relationship between disease progress and presence of the percent viruliferous population of whitefly at different locations and at different time intervals. Observations on whitefly population, viruliferous whitefly and CLCuD progress were recorded only from one cotton field from each location (hot spots) during 2011 and 2012. Three observations on whitefly population per three leaves (top, middle and bottom strata) on tagged plants were taken during the months of July, August and October in 2011 and 2012. Data were recorded from 40 randomly selected plants at each location of one acre by selecting 10 plants from four points in each field. CLCuD disease incidence and severity was recorded from the same plants using 0-6 scale (Monga, 2014). The PDI was calculated using the formula mentioned under section 2.2.

\section{Detection of viruliferous whitefly}

Detection of viruliferous whitefly population from the total whitefly population collected from infected plants was achieved by PCR technique using $\mathrm{CLCuV}$ specific coat protein (CP) primer pair $\mathrm{CP}-\mathrm{F}$ and $\mathrm{CP}-\mathrm{R}$ and the relationship between viruliferous whiteflies and CLCuD PDI was worked out. To determine percent viruliferous population of whitefly the DNA was isolated from collected whitefly samples. Fifty whitefly samples were collected from each site at the time of each observation from where the whitefly population and CLCuD PDI recording was done. For DNA isolation, a single whitefly was crushed in $25 \mu$ extraction buffer [ $50 \mathrm{mM}$ Tris-Cl (pH 8.4) $-1 \mathrm{ml}, 50 \mathrm{mM} \mathrm{KCl}-1 \mathrm{ml}$, $0.45 \%$ Tween-20 -1 ml, 0.45\% NP-40 1-ml, Proteinase K $(10 \mathrm{mg} / \mathrm{ml})-30 \mu \mathrm{l}$ and $970 \mu \mathrm{l}$ distilled water] in $1.5 \mathrm{ml}$ eppendorf tube by the help of micro pestle (Tarsons). $25 \mu 1$ of extraction buffer was added to wash micro pestle and incubated at $65^{\circ} \mathrm{C}$ and $95^{\circ} \mathrm{C}$ for 45 min and $10 \mathrm{~min}$, respectively. After incubation the crude extracts were centrifuged at 12,300 rpm for $3 \mathrm{~min}$. DNA isolated from single whiteflies was stored at $-20{ }^{\circ} \mathrm{C}$. The purified DNA isolated from single whitefly was subjected to PCR to detect the presence of $\mathrm{CLCuV}$ using $\mathrm{CLCuV}$ specific coat protein (CP) primer pair $\mathrm{CP}-\mathrm{F}$ and $\mathrm{CP}-\mathrm{R}$. The nucleotide sequence of these primers are: primer F- 5'-CGG GAT CCA TGT CGA AGC GAG CTG CC - 3' and primer -R- 5'CCG GAA TTC ATA TCA ATT CGT TAC AGA GTC A -3' (Imperial Life Sciences). PCR amplification was achieved using the 50 $\mu 1$ reaction mixture using: Genomic DNA (50ng) - $2 \mu \mathrm{l}$; CP primer (Forward) CP-F and CP primer (Reverse) CP-R $1.5 \mu l$ each, PCR master mix (1 X) - $45 \mu$ l. PCR amplification was performed in a thermocycler (model PTC100, M. J. Research Inc., USA) under the following parameters: one cycle for initial denaturation at $95{ }^{\circ} \mathrm{C}$ for 4 min., 29 cycles of denaturation at $94^{\circ} \mathrm{C}$ for $30 \mathrm{sec}$., annealing at $55^{\circ} \mathrm{C}$ for $30 \mathrm{sec}$, and extension at $72^{\circ} \mathrm{C}$ for 45 sec. An additional cycle at $72{ }^{\circ} \mathrm{C}$ for $10 \mathrm{~min}$. was run at the end of these cycles (Chakrabarty et al., 2005). After PCR, the 
PCR products $(10 \mu \mathrm{l})$ were resolved by submerged horizontal electrophoresis (Tarsons India Ltd) in $1 \%(\mathrm{w} / \mathrm{v})$ Agarose gel (containing ethidium bromide) in TrisAcetate-EDTA buffer ( $\mathrm{pH}$ 8.0) and electrophoresis was carried out at constant voltage of 80 Volt for $1 \mathrm{~h}$. The gel was visualized in ultraviolet light $(260 \mathrm{~nm})$ and photography was done by using gel documentation system. The 1000 bp DNA ladder was used to determine the size of the CLCuV DNA bands. Out of the total whitefly samples collected from each location at every observation, positive and negative samples were used for calculation of percent viruliferous whitefly population at each location and analysis of correlation. Along with viruliferous whitefly the CLCuD infection of cotton was also confirmed for $\mathrm{CLCuV}$ detection from each location.

\section{Statistical analyses}

Simple $\mathrm{T}$ test was applied to determine the statistical significance of differences among the mean data of each experiment. Similarly, the correlation among whitefly population on cotton plants, CLCuD PDI and among whitefly population, percent viruliferous whitefly population and CLCuD PDI was determined using Pearson Spearman Rank and Kendall's Tau with the help of computer program OP Stats (Sheoran et al., 1998).

\section{Results and Discussion}

Percent viruliferous whitefly population and CLCuD PDI on cotton variety HS-6 during 2010 and 2011 at ICAR-CICR Sirsa

The presence of $771 \mathrm{bp}$ DNA band of CLCuV was recorded in $1 \%(\mathrm{w} / \mathrm{v})$ agarose gel in viruliferous positive whitefly samples as well as cotton plant showing CLCuD infection. The data on percent viruliferous whitefly were calculated based on presence and absence of
$\mathrm{CLCuV}$ in each of the collected whitefly samples out of the total whiteflies samples and was used for analysis of correlation (Fig. 1). When the percentage of viruliferous whiteflies was compared during 2010 and 2011, the population was more during 2010 than 2011. In June 2010, among the total whitefly population at ICAR-CICR Sirsa, the viruliferous whiteflies population was $7.14 \%$, while in 2011, they were $4.14 \%$ and the corresponding CLCuD PDI was 0.17 and $0.08 \%$, respectively. In July, percent viruliferous whiteflies were $17.64 \%$ and $14.13 \%$ and the corresponding CLCuD PDI was 7.86 and 4.98 during 2010 and 2011, respectively. In August, viruliferous whiteflies were $26.5 \%$ and $18.06 \%$ and CLCuD PDI were $59.32 \%$ and $27.41 \%$, recorded during 2010 and 2011, respectively. In September 2010 , viruliferous whitefly was observed to be $33.53 \%$, while in 2011 viruliferous whitefly was $22.22 \%$. The CLCuD PDI was $79.24 \%$ and $42.64 \%$ during September 2010 and 2011, respectively. During October 2010, 34.48\% viruliferous whiteflies were detected; while in 2011 at this time $27.72 \%$ viruliferous whitefly were detected. CLCuD PDI was $86.10 \%$ and $50.47 \%$ during October 2010 and 2011, respectively (Table 1).

The whitefly population during 2010 and 2011 from May to October varied from 0.0 to 4.33 and 0.41 to 5.14, respectively, without showing any particular trend in increase or decrease in population. However, the percent viruliferous whiteflies and CLCuD PDI showed an increasing trend from May to October. The pooled mean of two year data of whitefly population per three leaves per cotton plant and PDI of CLCuD had a positive correlation among each other. There was a significant positive correlation at $\mathrm{p}=0.01$ among viruliferous whitefly population and PDI CLCuD $\left(r^{2}=0.945\right)$. However, non significant positive correlation was recorded among whitefly population per three leaves 
per cotton plant and PDI of CLCuD $\left(r^{2}=\right.$ 0.633 ) and among whitefly population per three leaves per cotton plant and viruliferous whitefly population $\left(r^{2}=0.796\right)$ (Table 2$)$.

Whitefly population, percent viruliferous whiteflies and CLCuD PDI in Punjab, Haryana and Rajasthan during 2011 and 2012

Among the three hot spot areas, comparatively the whitefly population was maximum in Rajasthan and minimum in Punjab during 2011, while it was maximum in Punjab and minimum in Haryana during 2012. Whitefly population was observed to be in increasing trend from July to August, and then it decreased in October at all locations considered for the study and during both the year.

During 2011 in the month of July and August viruliferous whiteflies were recorded, but there was no CLCuD PDI among all the locations except in Punjab in August. During July 2011, maximum percent viruliferous population was recorded from Rajasthan (4.0\%), followed by Punjab (3.2\%) and Haryana (2.0\%). In August the population of viruliferous whitefly increased to the tune of $6.7 \%, 4.8 \%, 3.3 \%$ in Rajasthan, Punjab and Haryana, respectively. The viruliferous whitefly population was further reached to $10.7 \%$ and $6.4 \%$ in Rajasthan and Punjab, respectively, in the month of October, while in Haryana percent viruliferous population remained 3.3\% only. During July 2012 higher viruliferous whitefly population in Punjab $(16.0 \%)$ and Rajasthan (18.7\%) and which was further increased in the month of August to the tune of $28.7 \%$ and $27.0 \%$ in Rajasthan and Punjab, respectively. During October, percent viruliferous increased upto $35.3 \%$ in Rajasthan and $15.3 \%$ in Haryana. PDI of $\mathrm{CLCuD}$ was recorded to be slightly higher in Rajasthan in comparison to Haryana and
Punjab during 2011 while the PDI of CLCuD was much higher in Rajasthan followed by Punjab during 2012. During 2011 in the month of July and August, CLCuD was not observed in Haryana and Rajasthan, but in Punjab PDI of CLCuD was only $0.6 \%$ in August. During October 2011, PDI of CLCuD was also observed in Rajasthan (4.0\%), Punjab (2.2\%) and Haryana (1.7\%). During 2012 in the month of July, maximum PDI of CLCuD was recorded in Rajasthan (24.3\%), followed by Punjab (18.5\%) and Haryana (3.3\%). During August 2012, the PDI was increased upto $42.3 \%$ in Rajasthan, $33.0 \%$ in Punjab and $10.7 \%$ in Haryana. Which was further increased in the month of October upto $55.7 \%$ in Rajasthan and $17.7 \%$ in Haryana (Table 3).

Pooled mean of two year data indicates that overall viruliferous whitefly population and PDI of CLCuD were recorded to be higher in Rajasthan and Punjab compared to Haryana. Similarly, an increasing trend of per cent viruliferous population and PDI of CLCuD was observed from July to October, during both the years. Percent viruliferous whitefly per three leaves per cotton plant and PDI of CLCuD showed a significant positive correlation $(\mathrm{p}=0.05)$ among each other. However, highly significant correlation $(\mathrm{p}=0.01)$ was recorded in between CLCuD PDI (\%) and percent viruliferous whiteflies $\left(r^{2}=0.995\right)($ Table 4).

Results of two years data collected during 2010 and 2011 showed an increasing trend in whitefly population from the month of May to September and later decreased in on-station experiments carried out at ICAR-CICR, Sirsa while increasing trend in viruliferous whitefly population as well as CLCuD PDI from May to October was recorded. By observing the two years data, it is clear that during 2010, CLCuD PDI was high in comparison to 2011. Disease progression and viruliferous whitefly population were higher in 2010 from June to 
October compared to 2011 at ICAR-CICR. The CLCuD PDI increased with the increase in viruliferous whitefly population. The total whitefly population in general does not correlate with PDI of disease, whereas it is the viruliferous nature of the whitefly which is important and has correlation for CLCuD PDI. Earlier studies have also reported that single B. tabaci is able to transmit the leaf curl virus agent (Sharma and Rishi, 2003), but greater transmission efficiency is observed when a higher number $B$. tabaci (more than 10 whiteflies per plant) is present (Cauquil and Follin, 2003). The general whitefly population during 2010 was peaked in July however, during 2011 it peaked only in September. The reasons behind this are higher relative humidity $(>82 \%)$, minimum temperature $(\sim 25$ $\left.{ }^{\circ} \mathrm{C}\right)$, rainfall $(3-10 \mathrm{~mm})$ and sunshine hours (Table 5). In the current study, whitefly population showed significant negative correlation with maximum temperature, significant positive correlation with relative humidity (morning and evening) and sunshine, while non-significant negative correlation was observed with minimum temperature and positive non-significant correlation with rainfall. Similarly, the PDI of CLCuD showed significant negative correlation with maximum and minimum temperature, significant positive correlation with relative humidity in the morning and sunshine, while non-significant positive-non-significant correlation with evening temperature, evening relative humidity, rainfall and whitefly population (Table 6). Janu and Dhiya (2017) have reported whitefly population in cotton to be significantly and positively correlated with the minimum temperature, morning and evening relative humidity while, significantly and negatively correlated with maximum temperature. This study also indirectly confirms that the more whiteflies probably will have more viruliferous ones, thereby leading to more transmission (Singh et al., 1994; Mann and Singh, 2004). However, at on-station trial in May 2011, 2.78\% viruliferous whiteflies were recorded but CLCuD PDI was negligible. During the beginning correlation observed between percent viruliferous whitefly and PDI at one moment could not necessarily explain what is happening in field at the same moment. However, this indicates that there may be delay between inoculation of the virus through whitefly and symptoms appearance, and the CLCuD PDI values depend on this delay. Moreover, the CLCuD symptoms appear only on young leaves one month after inoculation which results in very low PDI (Khan and Ahmad 2005). Subsequently, two months after inoculation of the virus the CLCuD PDI will increase. The pooled data of the two years study at on-station trial suggest that increase in viruliferous whitefly population increases CLCuD PDI in subsequent time i.e. about 3-4 week time later which might be due to incubation period required for symptom appearance. Previous serial transmission studies showed that $B$. tabaci adults could retain the virus for $9 \mathrm{~d}$ to entire life span. However, the serially transferred viruliferous whiteflies were not consistent in transmitting the virus in new plants i.e., the whiteflies transmitted the virus to new plants on day 1,2 , 5 or 8, but not transmitted on day 3, 4, 6 or 7 (Mann and Singh 2004). The exact reasons why all whiteflies in a population do not become viruliferous are not understood. All these studies indicate the various factors influencing cotton leaf curl virus disease incidence and its intensity. Percent viruliferous whiteflies population correlation with PDI of CLCuD in our studies shows a new and very important observation which can help us in prediction of disease and its management more accurately. The virus transmission is also shown to be a direct fraction of the number of viruliferous whiteflies per plant in several virus transmission studies including CLCuV. It has been demonstrated that when single whitefly 
per plant was allowed an acquisition access period of 24 h., $20 \%$ of the experimental whiteflies acquired the virus to induce $\mathrm{CLCuV}$ symptoms on healthy cotton plants. The percentage of transmission increased to 80,87 , 85,90 and 88 when the number of whiteflies was increased to $5,10,15,20$ and 25 per plant, respectively (Singh et al., 1994; Mann and Singh, 2004). In addition to host suitability and plant age, $\mathrm{CLCuV}$ acquisition is influenced by the severity of disease symptoms or the virus titer present in plants. B. tabaci acquired $\mathrm{CLCuV}$ more efficiently from heavily diseased plants than from less severely infected plants (Singh et al., 2000; Singh et al., 2001). Disease severity of the rice strip virus (RSV) was reported to be positively correlated with viruliferous rate of the vector but not with the population density of the insect, suggesting that the percentage of vectors infected by the virus rather than the total number of vectors play an important role in RSV epidemics and could be used for disease forecasting (He et al., 2016). The epidemic and outbreak of rice stripe disease are closely related to the occurrence of viruliferous small brown planthopper populations- Laodelphax striatellus Falle'n (Hibino 1996). These findings support the current study where we have also found that more the viruliferous whitefly population and severe is the CLCuD PDI at later crop stage.

A significant positive correlation $(\mathrm{P}=0.01)$ among pooled mean of two years data on viruliferous whitefly population and PDI CLCuD $\left(r^{2}=0.945\right)$ was recorded. Non significant positive correlation among whitefly population per three leaves per cotton plant and PDI of CLCuD $\left(\mathrm{r}^{2}=0.633\right)$ and among whitefly population per three leaves per cotton plant and viruliferous whitefly population $\left(\mathrm{r}^{2}=\right.$ 0.796), indicates that the increase in whitefly population also has positive relationship with viruliferous whiteflies as well as with PDI. However, these correlations were not significant. A non-significant correlation between CLCuD intensity and whitefly population on different varieties studied were also reported by Varma and Malathi (2003) however, Aktar et al., (2004) have not been able to eastablish a significant positive correlation of whitefly populations vis-à-vis disease development and its severity. Many other researchers also found non-significant relationship of whitefly population with disease incidence (Briddon and Markham 1994; Hameed et al., 1994; Iqbal, 2003). Some workers have found non-significant correlation of weekly maximum air temperature $\left({ }^{0} \mathrm{C}\right), \%$ relative humidity $(5$ p.m.), wind velocity, rainfall, sunshine and whitefly population on thirteen mutant/varieties and negative significant correlation between minimum air temperature and wind velocity (8 a.m.) for CLCuV disease development (Khan and Khan, 2000). Maharshi et al., (2017) have reported that percent CLCuD incidence and whitefly population have a significant negative correlation with temperature maximum and minimum, while positively correlated with relative humidity morning and evening. Monga et al., (2010) have not observed any correlation between general whitefly population and CLCuD incidence from 1999 to 2009, however, they observed that minimum temperature and sunshine hours have significant negative correlation whereas morning/evening relative humidity and rainfall have positive correlations with incidence and progress of CLCuD and developed regression equation which could be helpful in understanding factors affecting disease development and its prediction. The present study, we found a non-significant though positive correlation among whitefly population and CLCuD PDI, however, a significant positive correlation between population level of viruliferous whitefly and $\mathrm{CLCuD}$. Hence, the results clearly indicate the role of the level of viruliferous whitefly and 
CLCuD PDI. The findings of the current study will support in $\mathrm{CLCuD}$ management and to minimize the cotton crop loss due to CLCuD and suggests the monitoring and estimation of viruliferous whitefly are essential rather than non-viruliferous whitefly.

To further to confirm the correlation between the whitefly population, viruliferous whitefly population and CLCuD PDI the study was conducted in farmer fields in Punjab (five location), Rajasthan (three location) and
Haryana (three locations) during 2011 and 2012.

The study indicated that whitefly population was maximum in Rajasthan and minimum in Punjab during 2011 while it was maximum in Punjab and minimum in Haryana during 2012. A similar trend was observed in term of whitefly population increase from July to August, and then decrease in October at all locations and in both the year.

Table.1 Effect of percent viruliferous population on PDI of CLCuD during 2010 and 2011 at ICAR-CICR Sirsa

\begin{tabular}{|c|c|c|c|c|c|c|c|c|c|}
\hline \multirow[t]{2}{*}{$\begin{array}{l}\text { Observation } \\
\text { Months }\end{array}$} & \multicolumn{2}{|c|}{ Whitefly $^{\mathrm{a}}$} & \multirow[t]{2}{*}{$\begin{array}{l}\text { Pooled } \\
\text { mean }\end{array}$} & \multicolumn{2}{|c|}{$\begin{array}{l}\text { Viruliferous } \\
\text { whiteflies (\%) }\end{array}$} & \multirow[t]{2}{*}{$\begin{array}{l}\text { Pooled } \\
\text { mean }\end{array}$} & \multicolumn{2}{|c|}{$\begin{array}{l}\text { CLCuD PDI } \\
(\%)\end{array}$} & \multirow[t]{2}{*}{$\begin{array}{l}\text { Pooled } \\
\text { mean }\end{array}$} \\
\hline & 2010 & 2011 & & 2010 & 2011 & & 2010 & 2011 & \\
\hline May & 0.00 & 0.41 & 0.21 & 0.00 & 2.78 & 1.39 & 0.00 & 0.00 & 0.00 \\
\hline June & 1.84 & 0.54 & 1.19 & 7.14 & 4.14 & 5.64 & 0.17 & 0.08 & 0.13 \\
\hline July & 4.33 & 1.86 & 3.10 & 17.64 & 14.13 & 15.89 & 7.86 & 4.98 & 6.42 \\
\hline August & 3.42 & 3.68 & 3.55 & 26.5 & 18.06 & 22.28 & 59.32 & 27.41 & 43.37 \\
\hline September & 2.40 & 5.14 & 3.77 & 33.53 & 22.22 & 27.88 & 79.24 & 42.64 & 60.94 \\
\hline October & 2.08 & 2.58 & 2.33 & 34.48 & 27.72 & 31.1 & 86.1 & 50.47 & 68.29 \\
\hline Mean & 2.35 & 2.37 & 2.36 & 19.88 & 14.84 & 17.36 & 38.78 & 20.93 & 29.86 \\
\hline $\begin{array}{l}\text { T value }= \\
0.05\end{array}$ & 3.80 & 3.09 & 4.01 & 3.42 & 3.66 & 3.54 & 2.34 & 2.28 & 2.32 \\
\hline Probability & 0.0126 & 0.0271 & 0.0102 & 0.0187 & 0.0147 & 0.0166 & 0.0667 & 0.0714 & 0.068 \\
\hline
\end{tabular}

Table.2 Correlation of whitefly population, percent viruliferous population on PDI of CLCuD during 2010 and 2011 at ICAR-CICR Sirsa

\begin{tabular}{|c|c|c|c|c|}
\hline Observations & Whitefly $^{\mathrm{a}}$ & $\begin{array}{l}\text { Viruliferous } \\
\text { whiteflies (\%) }\end{array}$ & $\begin{array}{l}\text { CLCuD PDI } \\
(\%)\end{array}$ & S. Error \\
\hline Whitefly $^{a}$ & 1.000 & & & 0.576 \\
\hline Viruliferous whiteflies (\%) & $0.796^{\mathrm{NS}}$ & 1.000 & & 4.893 \\
\hline CLCuD PDI (\%) & $0.633^{\mathrm{NS}}$ & $0.945^{* * *}$ & 1.000 & 12.846 \\
\hline
\end{tabular}


Table.3 Whitefly population, per cent viruliferous whiteflies and PDI of CLCuD in cotton fields in Punjab, Haryana and Rajasthan during 2011 and 2012

\begin{tabular}{|c|c|c|c|c|c|c|c|c|c|c|c|c|}
\hline \multirow[t]{2}{*}{ Observations } & \multirow{2}{*}{$\begin{array}{l}\text { Observation } \\
\text { Months }\end{array}$} & \multicolumn{3}{|c|}{ Punjab* } & \multicolumn{3}{|c|}{ Haryana** } & \multicolumn{3}{|c|}{ Rajasthan** } & \multirow[b]{2}{*}{$\begin{array}{c}\mathrm{T} \\
\text { values } \\
=0.05\end{array}$} & \multirow[b]{2}{*}{$\begin{array}{c}\text { Probab } \\
\text { ility }\end{array}$} \\
\hline & & 2011 & $2012^{\mathrm{a}}$ & $\begin{array}{c}\text { Pooled } \\
\text { mean }\end{array}$ & 2011 & 2012 & $\begin{array}{c}\text { Pooled } \\
\text { mean }\end{array}$ & 2011 & 2012 & $\begin{array}{c}\text { Pooled } \\
\text { mean }\end{array}$ & & \\
\hline \multirow{3}{*}{$\begin{array}{l}\text { Whitefly/3 } \\
\text { leaves/plant }\end{array}$} & July & 3.2 & 5.2 & 4.2 & 4.4 & 4.3 & 4.35 & 5.9 & 5.1 & 5.5 & 16.98 & 0.0000 \\
\hline & August & 4.3 & 6.4 & 5.35 & 5.3 & 5.8 & 5.55 & 6.7 & 5.7 & 6.2 & 23.93 & 0.0000 \\
\hline & October & 4.0 & - & 2 & 4.7 & 4.9 & 4.8 & 6.1 & 5.5 & 5.8 & 6.28 & 0.0002 \\
\hline \multirow{3}{*}{$\begin{array}{l}\text { Viruliferous } \\
\text { whiteflies } \\
(\%)\end{array}$} & July & 3.2 & 16 & 9.6 & 2.0 & 4.0 & 3.0 & 4.0 & 18.7 & 11.35 & 3.83 & 0.005 \\
\hline & August & 4.8 & 27 & 15.9 & 3.3 & 10 & 6.65 & 6.7 & 28.7 & 17.7 & 4.22 & 0.0029 \\
\hline & October & 6.4 & - & 3.2 & 3.3 & 15.3 & 9.3 & 10.7 & 35.3 & 23 & 3.14 & 0.0137 \\
\hline \multirow{3}{*}{$\begin{array}{l}\text { CLCuD } \\
\text { PDI }(\%)\end{array}$} & July & 0.0 & 18.5 & 9.25 & 0.0 & 3.3 & 1.65 & 0.0 & 24.3 & 12.15 & 2.54 & 0.0345 \\
\hline & August & 0.6 & 33 & 16.8 & 0.0 & 10.7 & 5.35 & 0.0 & 42.3 & 21.15 & 2.82 & 0.0226 \\
\hline & October & 2.2 & - & 1.1 & 1.7 & 17.7 & 9.7 & 4.0 & 55.7 & 29.85 & 2.18 & 0.0613 \\
\hline \multicolumn{13}{|c|}{$\begin{array}{l}* \text { Mean of five locations } \\
* * \text { Mean of three locations } \\
{ }^{\text {a }} \text { During the October } 2012 \text { t }\end{array}$} \\
\hline
\end{tabular}

Table.4 Correlation matrices among whitefly/3 leaves/plant, percent viruliferous whiteflies and CLCuD PDI (\%) in cotton fields in Punjab, Haryana and Rajasthan during 2011 and 2012

\begin{tabular}{|c|c|c|c|c|}
\hline Observations & Whitefly $^{\mathrm{a}}$ & $\begin{array}{l}\text { Viruliferous } \\
\text { whiteflies (\%) }\end{array}$ & $\begin{array}{l}\text { CLCuD PDI } \\
(\%)\end{array}$ & $\begin{array}{l}\text { Std. } \\
\text { Error }\end{array}$ \\
\hline Whitefly $^{a}$ & 1.000 & & & 0.571 \\
\hline Viruliferous whiteflies (\%) & $0.698^{*}$ & 1.000 & & 2.020 \\
\hline CLCuD PDI (\%) & $0.689^{*}$ & $0.995^{* *}$ & 1.000 & 2.729 \\
\hline \multicolumn{5}{|c|}{$\begin{array}{l}\text { a average of whitefly population recorded from } 3 \text { leaves (upper middle and lower) per plant } \\
{ }^{*} \text { Statistically significant at } \mathrm{p}=0.005 \\
\text { "Statistically significant at } \mathrm{p}=\mathbf{0 . 0 1}\end{array}$} \\
\hline
\end{tabular}


Table.5 Whitefly population and disease progress in relation to weather factors at CICR Sirsa during 2010 and 2011

\begin{tabular}{|l|c|c|c|c|c|c|c|c|}
\hline & \multicolumn{9}{|c|}{$\mathbf{9 0 1 0}$} \\
\hline Months & $\begin{array}{c}\text { CLCuD } \\
\text { Incidence } \\
\%\end{array}$ & $\begin{array}{c}\text { WF/3 } \\
\text { leaves }\end{array}$ & $\begin{array}{c}\text { Max. } \\
\text { Temp }\end{array}$ & $\begin{array}{c}\text { Min. } \\
\text { Temp } \\
\text { June }\end{array}$ & $\begin{array}{c}\text { Morning } \\
\text { RH }\end{array}$ & $\begin{array}{c}\text { Evening } \\
\text { RH }\end{array}$ & Rainfall & $\begin{array}{c}\text { Sunshine } \\
\text { hours }\end{array}$ \\
\hline July & 0.2 & 1.8 & 40.0 & 26.5 & 56.0 & 29.0 & 0.0 & 2.2 \\
\hline Aug & 4.3 & 4.3 & 36.3 & 27.3 & 81.3 & 52.8 & 10.1 & 3.7 \\
\hline September & 77.5 & 2.4 & 33.8 & 25.4 & 87.0 & 59.0 & 7.6 & 6.4 \\
\hline October & 86.1 & 2.1 & 34.5 & 22.9 & 83.0 & 39.0 & 0.0 & 5.4 \\
\hline & & & & & 2011 & & & \\
\hline June & 0.1 & 0.5 & 38.7 & 28.0 & 73.5 & 49.0 & 0.0 & 0.8 \\
\hline July & 2.5 & 1.8 & 37.2 & 28.1 & 75.0 & 50.8 & 0.0 & 3.9 \\
\hline Aug & 22.9 & 3.7 & 33.9 & 26.4 & 87.1 & 70.3 & 7.2 & 5.2 \\
\hline September & 40.7 & 5.1 & 33.1 & 25.2 & 87.1 & 63.6 & 3.7 & 3.8 \\
\hline October & 48.8 & 2.6 & 34.1 & 21.1 & 75.6 & 40.5 & 0.0 & 8.8 \\
\hline
\end{tabular}

Table.6 Correlation between different weather parameters with whitefly population build up and disease incidence (pooled over 2010 and 2011)

\begin{tabular}{|l|c|c|c|}
\hline \multicolumn{1}{|c|}{$\begin{array}{c}\text { Weather } \\
\text { parameters }\end{array}$} & Whitefly & PDI (\%) & Std Error \\
\hline Temperature & & & \\
\hline Maximum & $-0.717^{*}$ & $-0.808^{*}$ & 0.214 \\
\hline Minimum & $-0.044^{\mathrm{NS}}$ & $-0.751^{*}$ & 1.526 \\
\hline & Relative humidity & & 1.237 \\
\hline Morning & $0.574^{*}$ & $0.530^{*}$ & 2.310 \\
\hline Evening & $0.683^{*}$ & $0.281^{\mathrm{NS}}$ & 2.162 \\
\hline Rainfall & $0.189^{\mathrm{NS}}$ & $0.086^{\mathrm{NS}}$ & 3.214 \\
\hline Sunshine & $0.484^{*}$ & $0.498^{*}$ & 1.237 \\
\hline Whitefly & - & $0.481^{\mathrm{NS}}$ & \\
\hline
\end{tabular}


Fig.1 PCR amplification of CLCuV-DNA (771bp) in whitefly collected from cotton field at ICAR-CICR Regional Station during 2010-2011 by PCR (Lane M-100 bp molecular weight marker, Lane C- positive check, Lane 1-36 whitefly DNA)

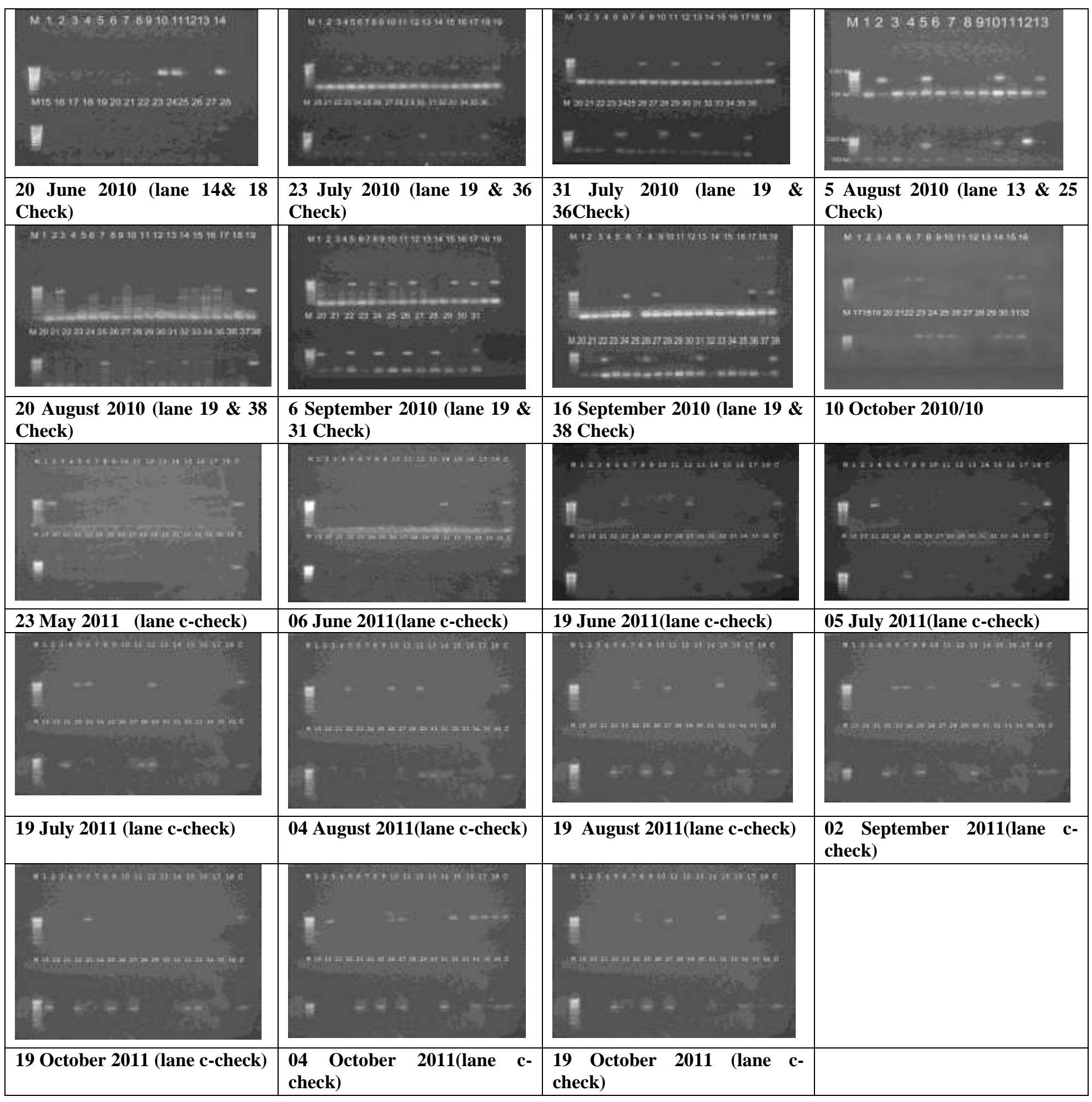


Pooled mean of two year data indicates that the overall viruliferous whitefly population and PDI of CLCuD were recorded to be higher in Rajasthan and Punjab compared to Haryana. Similarly, an increasing trend of per cent viruliferous population and PDI of CLCuD was observed from July to October, during both the years. Similarly, to the present study, the $\mathrm{CLCuV}$ incidence is reported to increase from 4.3 to $12.3 \%$ during the end of July and first week of August in Pakistan (Ali et al., 1995).

While, the progress of the disease was reported to be maximum during the month of August as compared to July and September in Northern India (Monga et al., 1998). As, in the present study, a less number of viruliferous whitefly $(<7 \%)$ with negligible amount of PDI were recorded during July and August 2011 in all the three locations (Table 3). Moreover, in the on-station trail at ICARSirsa, the presence of viruliferous whitefly was detected during the month of May 2011, however, the CLCuD symptoms were recorded during June. The absence of PDI during the corresponding months in the hot spot area may also be due to the lower whitefly population as well as delay between inoculation of the virus and the expression of the symptom level. These results are similar to the on-station trial and also previous transmission studies which showed that $\mathrm{CLCuV}$ could be acquired by whitefly within $4 \mathrm{~h}$, transmit the virus within $1 \mathrm{hr}$ of feeding and symptoms are recorded after 4 weeks (Khan and Ahmad, 2005). In this study conducted at multi-location trials, highly significant correlation $(\mathrm{p}=0.1)$ was recorded in between PDI of CLCuD PDI (\%) and percent viruliferous whiteflies $\left(\mathrm{r}^{2}=0.995\right)$. Moreover, a significant positive correlation $(\mathrm{p}=0.5)$ was found among whitefly population per three leaves per plant, percent viruliferous whitefly per three leaves per cotton plant and PDI of CLCuD. However, from the this study it can be concluded that percent viruliferous whiteflies increases continuously from June to early October and decreases at the end of October. Corresponding to the percent viruliferous whiteflies population, the CLCuD PDI also increases in the same manner and becomes constant at the end of October.

The current study conducted both at onstation and hot spot areas of three different agroclimatic conditions, strengthen our understanding about the epidemiology of $\mathrm{CLCuV}$ for improved forecasting to manage the disease monitoring and detection of viruliferous whiteflies rather than total whitefly population. CLCuD PDI primarily depends on the presence of viruliferous whiteflies in the environment. Additionally, the study holds the importance in controlling the transmission of CLCuV through timely detection of viruliferous whitefly level in the field during the off-season as well as during the crop season from cotton and other alternate plant-hosts. Thus, timely detection of viruliferous whitefly level can serve as a useful tool which will help in timely application of the appropriate management strategies for management of viruliferous whitefly and ultimately reducing CLCuD PDI.

\section{Conflict of interest}

This is to submit that that the work described in the paper has not been published before; that it is not under consideration for publication anywhere else; that its publication has been approved by all co-authors, as well as by the responsible authorities - tacitly or explicitly - at the institute where the work has been carried out. The publisher will not be held legally responsible should there be any claims for compensation. All authors are wishing to include figures, tables, or text passages that have not been published elsewhere. 


\section{Key Message}

This is one of its first kinds of research study which shows a positive correlation between viruliferous whitefly population and the level of CLCuD intensity in cotton field for the first time. The field and lab studies advances our understanding in making the decision for management of viruliferous whitefly and ultimately reducing CLCuD PDI. Regular monitoring and timely detection of viruliferous whitefly level in fields can serve as a useful tool for reducing transmission of CLCuD.

\section{References}

Akhtar, K.P., Hussain, M., Khan, A.I., Haq, M.A. and Iqbal, M.M. (2004) Influence of plant age, whitefly population and cultivar resistance on infection of cotton plants by cotton leaf curl virus (CLCuV) in Pakistan, Field Crops Research 86, 5-21.

Ali, M., Ahmed, Z., Tanveer, M. and Mahmood, T. (1995) Cotton leaf curl virus in the Punjab. Current Situation and review of work. Central Cotton Research Institute/Ministry of Food and Agric, Livestock. Govt. Pakistan/Asian Development Bank, 35-36 pp.

Briddon, R.W. and Markham, P.G. (1994) Universal primers for dicot-infecting geminiviruses, Molicular Biotechnology 1, 202-205.

Brown, J.K., Ur-Rehman, M.Z., Avelar, S., Chingandu, N., Hameed, U, Haider, S. and Ilyas M (2017) Molecular diagnostic development for begomovirus-betasatellite complexes undergoing diversification: A case study, Virus. Res. https://doi.org/10.1016/j.virusres.2017.0 4.014 .

Cauquil, J. and Follin, J.C. (1983) Presumed virus and mycoplasm-like organism disease in subsaharan Africa and the rest of the world. Coton et fibres Tropicals 38, 93-317 DOI: https://www.cabdirect.org/cabdirect/abs tract/19846751050

Chakrabarty, P.K., Sable, S., Monga, D. and Mayee, C. D. (2005) Polymerase chain reactionbased detection of Xanthomonas axonopodis pv malvacearum and cotton leaf curl virus, Indian Journal of Agricultural Sciences 75, 524-27.

Datta, S., Budhauliya, $\quad$ R., Das, B., Gopalakrishnan, R., Sharma, S., Chatterjee, S., Vanlalhmuaka, Raju, P.S., and Veer, V. (2017) Rebound of Cotton leaf curl Multan virus and its exclusive detection in cotton leaf curl disease outbreak, Punjab (India) (2015) Scientific Reports 7(1),17361. doi: 10.1038/s41598-017-17680-9.

Hameed, S., Khalid, S., Haq, E. and Hashmi, A.A. (1994). Cotton leaf curl disease in Pakistan caused by a whitefly transmitted geminivirus, Pl Dis 78, 529 DOI:

https://www.apsnet.org/publications/pla ntdisease/backissues/ Documents/ 1994 Abstracts/PD_78_0529H.htm.

He, D.C., Zhan, J., Cheng, Z.B. and Xie, L.H. (2016) Viruliferous rate of small brown plant hopper is a good indicator of rice stripe disease epidemics, Scientific Reports 6, 21376. http://doi.org/10.1038/srep21376.

Hibino, H. (1996). Biology and epidemiology of rice viruses, Annual Review of Phytopathology 34, 249-274.

Idris, A.M. (1990). Cotton leaf curl virus disease in the Sudan. Mededelingen Landbouwwetenschapper Rijksuniversiteit Gent 55:263-267 DOI: http://agris.fao.org/agrissearch/search.do?recordID=BE9200517

Iqbal, M. (1993). Detection, transmission and control of cotton leaf curl virus. M.Sc 
Thesis, Deptt Agri Ent Univ Agric., Faisalabad, p. 55.

Janu, A and Dahiya, K.K. (2017) Influence of weather parameters on population of whitefly, Bemisia tabaci in American cotton (Gossypium hirsutum), Journal of Entomology and Zoology Studies 5(4), 649-654.

Khan, M.A. and Khan, H.A. (2000). Cotton leaf curl virus disease severity in relation to environmental conditions. Pakistan Journal of Biological Sciences, $\quad 3, \quad 1688-1690$ DOI: http://www.docsdrive.com/pdfs/ansinet/ pjbs/2000/1688-1690.pdf

Khan, J.A. and Ahmad, J. (2005). Diagnosis, monitoring and transmission characteristics of cotton leaf curl virus, Current Science 88(11), 1803-1809.

Maharshi, A., Yadav, N.K., Swami, P., Singh, P. and Singh, J. (2017). Progression of cotton leaf curl disease and its vector whitefly under weather influences, International Journal of Current Microbiology and Applied Sciences 6(5), 2663-2670.

Mann, R.S. and Singh, L, (2004), Studies on the interaction of cotton leaf curl virus $(\mathrm{CLCuV})$ with its vector $B$. tabaci (Genn.), Journal of Cotton Research and Development 18, 95-98

Monga, D. (2014). Cotton Leaf Curl Virus diseases. Central Institute for Cotton Research, Regional Station, Sirsa 125055, India.

Monga, D., Chakrabarty, P.K. and Kranthi, K.R. (2011a) Cotton leaf Curl Disease in India-recent status and management strategies. Presented in 5th meeting of Asian Cotton Research and Development Network Held in Lahore in Feb 23-25.

Monga, D., Manocha, V., Kumhar, K.C. Soni, R. and Singh, N.P. (2011b) Occurrence and prediction of cotton leaf curl virus disease in northern zone, Journal of
Cotton Research and Development 25(2), 273-277

Monga, D., Raj, S. and Varma, S.K. (1998) Preliminary investigations on reaction of cotton germplasm to leaf curl and losses caused by the disease. National Symposium on "Present Scenario in diseases of Oilseeds and Pulses" held at Aurangabad from February 17-19.

Monga, D., Shree Lakshmi, B. and Prakash, A.H. (2013) Crop losses due to important cotton diseases. Central Institute for Cotton Research, Regional Station, Sirsa -125055, India.

Narula, A.M., Monga, D., Chauhan, M.S. and Raj, S. (1999) Cotton leaf curl virus disease in India-The Challenge ahead, Journal of Cotton Research and Development 13, 129-138.

Naveen, N.C., Chaubey, R., Kumar, D., Rebijith, K.B., Rajagopal, R., Subrahmanyam, B. and Subramanian, S. (2017). Insecticide resistance status in the whitefly, Bemisia tabaci genetic groups Asia-I, Asia-II-1 and Asia-II-7 on the Indian subcontinent, Scientific Reports 7, 40634. https://doi.org/10.1038/srep40634.

Rajagopalan, P.A., Naik, A., Katturi, P., Kurulekar, M., Kankanallu, R.S. and Anandalakshmi, R. (2012) Dominance of resistance-breaking cotton leaf curl Burewala virus $(\mathrm{CLCuBuV})$ in northwestern India, Archives of Virology 157, 855-868.

Sattar, M.N., Kvarnheden, A., Saeed, M. and Briddon, R.W. (2013) Cotton leaf curl disease-an emerging threat to cotton production worldwide, Journal of General Virology 94, 695-710.

Sattar, M.N., Iqbal, Z., Tahir, M.N. and Ullah, S. (2017) The Prediction of a New CLCuD Epidemic in the Old World, Frontiers in Microbiology 8, 631,https://doi.org/10.3389/fmicb.2017. 00631. 
Sharma, P. and Rishi, N. (2003) Host range and vector relationships of cotton leaf curl virus from northern India, Indian Phytopathology 56, 496-499

Sheoran, O.P., Tonk, D.S., Kaushik, L.S., Hasija, R.C. and Pannu, R.S. (1998) Statistical Software Package for Agricultural Research Workers. In: Hooda DS, Hasija RC (eds.), Recent Advances in information theory, Statistics and Computer Applications. Department of Mathematics Statistics, CCS HAU, Hisar, India, 139-143 pp.

Singh, D., Singh, R. and Garg, H.R. (2000) Screening of Cotton (Gossypium hirsutum L.) Germplasm Lines/Cultivars against Cotton Leaf Curl Virus (CLCuV), Journal of Cotton Research and Development 14,123-125. Singh, D., Singh, R., Garg, H.R. and Gill, J.S.
(2001) Incidence of cotton leaf curl virus $(\mathrm{CLCuV})$ and bacterial blight on upland cotton in the Punjab, Journal of Cotton Research and Development 15, 99-101.

Singh, J., Sohi, A.S., Mann, H.S. and Kapur, S.P. (1994) Studies on whitefly Bemisia tabaci (Genn.) transmitted cotton leaf curl virus disease in Punjab, Journal of Insect Science 7, 194-198.

Singh, M. (2000). Studies on the leaf curl disease of cotton caused by cotton leaf curl virus (CLCuV) in Punjab. Dissertation, Punjab agricultural University, Ludhiana.

Varma, A. and Malathi, V.G. (2003) Emerging geminivirus problems: a serious threat to crop production, Annals of Applied Biology 142, 145164.

\section{How to cite this article:}

Kumar, A., S.K. Sain and Monga, D. 2019. Study on Correlation between Population of Viruliferous Whitefly and the Percent Intensity of Cotton Leaf Curl Disease in Cotton. Int.J.Curr.Microbiol.App.Sci. 8(01): 922-937. doi: https://doi.org/10.20546/ijcmas.2019.801.100 